\title{
Sanksi Terhadap Notaris Yang Melakukan Tindak Pidana Menurut Peraturan Perundang-Undangan Di Indonesia
}

\section{Nur Cahyanti', Budi Raharjo ${ }^{* *}$, Sri Endah Wahyuningsih ${ }^{* *}$}

\author{
(S2) Kenotariatan Fakultas Hukum UNISSULA, Semarang email : \\ nutcahyanti@gmail.com \\ ** Mahasiswa Program Magister \\ budiraharjo2811@yahoo.com \\ ${ }^{* * *}$ Dosen Fakultas Hukum UNISSULA \\ (S2) Ilmu Hukum, Fakultas Hukum UNISSULA, Semarang, e-mail:
}

\begin{abstract}
ABSTRAK
Tujuan penelitian ini adalah: Untuk menganalisis perbuatan yang merupakan tindak pidana yang bisa dilakukan oleh notaris menurut hukum positif saat ini dan untuk menganalisis terhadap notaris yang melakukan tindak pidana menurut perundang-undangan di Indonesia? Penelitian ini adalah dengan pendekatan yuridis-normatif yang bersumber dari pengumpulan data yang diperoleh dari data primer dan data sekunder, kemudian dianalisis dengan metode analisis kualitatif. Teknik pengumpulan data yang digunakan adalah studi kepustakaan. Teknik analisis data menggunakan analisis data kualitatif.

Hasil temuan peneliti menunjukkan bahwa tindak pidana yang dapat dilakukan oleh notaris adalah pemalsuan, terhadap akta (akta fiktif), keterangan dalam akta, legalisasi, waarmerking, pencocokan fotocopy, dan tanda tangan; Penggelapan, bahwa mengaku sebagai milik sendiri segala sesuatu barang sebagian/seluruhnya yang ada dalam kekuasaan Notaris, dititipkan dengan dasar kepercayaan kerena kewenangan Notaris yang bukan milik/kepunyaan Notaris; Penipuan, bahwa melakukan kebohongan/rangkaian kebohongan/tipu muslihat untuk menguntungkan Notaris secara melawan hukum/tidak sesuai dengan ketentuan. Tidak adanya sanksi pidana dalam UUJN, peraturan yang mengatur mengenai sanksi terhadap Notaris menjadi kurang sempurna, karena tidak adanya sanksi yang tegas dan sanksi yang jelas akan tindakan-tindakan yang dikategorikan tindak pidana khusus yang hanya dapat dilakukan oleh Notaris yaitu Tindak Pidana Notaris (TPN), yang kenyataannya belum ada satupun peraturan yang mengatur mengenai hal tersebut. Sanksi yang tersisa dalam UUJN hanyalah murni sanksi administratif dan sanksi perdata saja
\end{abstract}

Kata Kunci : Sanksi, Notaris dan Tindak Pidana.

\section{ABSTRACT}

The purpose of this study are: To analyze the act which is a criminal act that can be done by notary according to the positive law at this time and to analyze to notary which do crime according to legislation in Indonesia?

This research is a juridical-normative approach that comes from collecting data obtained from primary data and secondary data, then analyzed by qualitative analysis method. The data collection technique used is literature study. Data analysis techniques used qualitative data analysis.

The findings of the researcher indicate that the criminal act which can be done by a notary is falsification, to deed (fictitious deed), statement in deed, legalization, waarmerking, copying match, and signature; The embezzlement, that claims to be the property of all things in part / entirely existing in the power of a Notary, is entrusted with the basis of trust because of the authority of a Notary who does not belong to a Notary; Fraud, that lie / series of lies / deceptions to benefit Notaries unlawfully / not in accordance with the provisions. In the absence of criminal sanctions in the UUJN, the regulations governing sanctions against Notary become imperfect, due to the absence of strict sanctions and clear sanctions on acts categorized as special crimes that can only be done by Notaries namely the Criminal Act Notary (TPN), which in reality there is no single rule that regulates about it. The remaining sanctions in UUJN are purely administrative sanctions and civil sanctions only.

Key Words : Sanctions, Notaries and Criminal Acts.

\section{PENDAHULUAN}

Notaris sebagai pejabat umum memiliki peran sentral dalam menegakkan hukum di Indonesia, karena selain kuantitas notaris yang begitu besar, notaris dikenal masuk kelompok elit di Indonesia. Notaris berwenang membuat akta otentik dan memiliki posisi yang strategis dalam memberikan kepastian hukum kepada masyarakat khususnya bidang perikatan yang terjadi karena perjanjian. Ruang lingkup pertanggungjawaban notaris meliputi kebenaran formil atas akta yang dibuatnya. Notaris merupakan profesi hukum dan dengan demikian notaris adalah suatu profesi mulia (nobile officium). 
Disebut sebagai nobile officium dikarenakan profesi notaris sangat erat hubungannya dengan kemanusiaan. Akta yang dibuat oleh notaris dapat manjadi alas hukum atas status harta benda, hak dan kewajiban seseorang. Kekeliruan atas akta notaris dapat menyebabkan tercabutnya hak seseorang atau terbebaninya seseorang atas suatu kewajiban. ${ }^{1}$

Dengan demikian notaris dalam menjalankan tugas dan jabatannya haruslah selalu berpedoman pada peraturan perundang-undangan, kode etik, dan moral karena apabila terjadi pelanggaran yang dilakukan oleh notaris akan sangat merugikan para pihak. Apabila akta yang dibuatnya mengandung cacat hukum karena kesalahan notaris baik kelalaian maupun kesengajaan notaris itu sendiri maka notaris harus memberikan pertanggungjawaban secara moral dan secara hukum.

Sesuai dengan ketentuan Undang-Undang Nomor 2 Tahun 2014 tentang Jabatan Notaris yang menyatakan bahwa:"Isi akta tidak boleh diubah atau ditambah, baik berupa penulisan tindih, penyisipan, pencoretan, atau penghapusan dan menggantinya dengan yang lain." Penerbitan akta yang tanpa sepengetahuan Pemohon mengindikasikan adanya tindak pidana pemalsuan surat, sebagaimana diatur dalam Pasal 263 ayat (1) Kitab Undang-Undang Hukum Pidana (KUHP), yang berbunyi:

"Barangsiapa membuat surat palsu atau memalsukan surat yang dapat menimbulkan sesuatu hak, perikatan atau pembebasan hutang, atau yang diperuntukkan sebagai bukti dari pada sesuatu hal dengan maksud untuk memakai atau menyuruh orang lain memakai surat tersebut seolah-olah isinya benar dan tidak palsu, diancam jika pemakaian tersebut dapat menimbulkan kerugian, karena pemalsuan surat, dengan pidana penjara paling lama enam tahun."

Selanjutnya Pasal 264 ayat (1) ke-1 KUHP menyatakan bahwa:

"pemalsuan surat diancam dengan pidana penjara paling lama delapan tahun, jika dilakukan terhadap akta-akta otentik."

Dalam Pasal 84 dan Pasal 85 Undang-Undang No. 2 Tahun 2014 tentang perubahan atas UndangUndang No. 30 Tahun 2004 tentang Jabatan Notaris diatur bahwa ketika Notaris dalam menjalankan tugas jabatannya terbukti melakukan pelanggaran, maka notaris dapat dikenai atau dijatuhi sanksi, berupa sanksi perdata, administrasi, dan kode etik jabatan Notaris, dan sanksi-sanksi tersebut telah

\footnotetext{
1 Abdul Ghofur Anshori, 2009, Lembaga Kenotariatan Indonesia Perspektif Hukum dan Etika, UII Press, Yogyakarta, hlm. 25
}

diatur sedemikian rupa, baik sebelumnya dalam Peraturan Jabatan Notaris, dan sekarang dalam UUJN dan Kode Etik Jabatan Notaris, dan tidak mengatur adanya sanksi pidana terhadap notaris. Dalam praktik ditemukan kenyataan bahwa suatu tindakan hukum atau pelanggaran yang dilakukan Notaris sebenarnya dapat dijatuhi sanksi administrasi atau perdata atau kode etik jabatan Notaris, namun kemudian ditarik atau dikualifikasikan sebagai suatu tindak pidana yang dilakukan oleh notaris.

Aspek-aspek tersebut jika terbukti dilanggar oleh Notaris maka notaris yang bersangkutan dapat dijatuhi sanksi perdata atau administratif. Jika aspekaspek tersebut dapat dibuktikan dapat dijadikan dasar untuk menjatuhkan sanksi administratif dan sanksi perdata terhadap Notaris. Di sisi lain aspekaspek tersebut dapat dijadikan dasar untuk mempidanakan Notaris dengan dasar notaris telah membuat surat palsu atau memalsukan akta dengan kualifikasi sebagai suatu tindak pidana yang dilakukan oleh Notaris. $^{2}$

Pengaturan sanksi hukum dalam UUJN menunjukkan Notaris bukan sebagai subyek yang kebal terhadap hukum. Notaris disamping dijatuhi sanksi perdata dan administratif, juga dapat dijatuhi sanksi kode etik jabatan bahkan sanksi pidana. Sanksi etika dapat dijatuhkan terhadap Notaris yang melakukan pelanggaran terhadap Kode Etik Jabatan Notaris. Adapun sanksi pidana karena tidak diatur dalam UUJN, maka sanksi pidana akan dikenakan jika Notaris dalam menjalankan tugas jabatannya telah memenuhi unsur-unsur delik tertentu suatu tindak pidana berdasarkan Kitab Undang-Undang Hukum Pidana (KUHP). Dengan ketiadaan sanksi pidana dalam UUJN maka pengaturan mengenai sanksi terhadap Notaris menjadi kurang sempurna. Sanksi pidana menjadi penting dimasukkan dalam UUJN selain menjadikannya sebagai koridor dalam menjalankan kewenangannya, sanksi pidana juga bersifat preventif sebelum kejahatan terjadi. Sanksi pidana dalam UUJN juga sangat penting agar undang-undang tersebut berlaku efektif dan dapat menegakkan keadilan bagi masyarakat yang dirugikan akibat dari akta autentik tersebut yang dibuat oleh Notaris.

Dari beberapa permasalahan diatas, suatu hal yang wajar apabila sebagian orang berpendapat Notaris kebal terhadap hukum. Sehingga timbul pertanyaan mengenai urgensi penerapan Tindak Pidana Notaris (TPN) mengingat tidak terdapatnya sanksi pidana dalam UUJN tersebut yang membuat seorang Notaris tidak jera dengan masalah hukum

\footnotetext{
${ }^{2}$ Habib Adjie, 2014, Hukum Notaris Indonesia, Refika Aditama, Bandung, hlm. 25
} 
yang didahapinya. Oleh karena banyaknya permasalahan diatas, dalam hal ini penulis tertarik untuk membahas dan menganalisis mengenai latar belakang masalah yang telah diuraikan diatas dengan judul penelitian :"Sanksi Terhadap Notaris Yang Melakukan Tindak Pidana Menurut Peraturan Perundang-Undangan Di Indonesia".

Rumusan masalah dalam penelitian ini dapat dirumuskan sebagai berikut : 1) Apa perbuatan yang merupakan tindak pidana yang bisa dilakukan oleh notaris menurut hukum positif saat ini? 2) Apa sanksi terhadap notaris yang melakukan tindak pidana menurut perundang-undangan di Indonesia?

\section{Metode Penelitian}

Penelitian hukum ini termasuk dalam penelitian yuridis normatif. Dalam penelitian ini dipergunakan pendekatan perundang-undangan (the statue approach) dan pendekatan analisis konsep hukum (analitical \& Conseptual Approach). Pendekatan perundang-undangan (statue approach) dilakukan dengan menelaah atau mengkaji ketentuanketentuan hukum serta peraturan perundangundangan $^{3}$ yang mengatur tentang Sanksi Terhadap Notaris Yang Melakukan Tindak Pidana Menurut Peraturan Perundang-Undangan Di Indonesia. Teknik pengumpulan data yang digunakan dalam penelitian ini adalah dengan menggunakan metoda bola salju (snowball method). ${ }^{4}$ Teknik analisis bahan hukum dalam penelitian ini menggunakan teknik deskripsi dan tehnik analisis kuantitatif. Teknik deskripsi adalah menguraikan adanya suatu kondisi atau posisi dari proposisi-proposisi hukum atau non hukum, ${ }^{5}$ sedangkan teknik penemuan hukum menggunakan teknik konstruksi hukum dengan metode analogi adalah suatu bentuk penalaran dengan memperluas berlakunya suatu pasal dari aturan hukum atau undang-undang terhadap peristiwa.

\section{HASIL PENELITIAN DAN PEMBAHASAN}

\section{Perbuatan yang merupakan Tindak Pidana yang bisa dilakukan oleh Notaris menurut Hukum Positif saat ini}

Notaris sebagai seorang Pejabat Umum dihadirkan dengan maksud untuk membantu dan melayani masyarakat yang membutuhkan

\footnotetext{
${ }^{3}$ Peter Mahmud Marzuki II, Loc.Cit.

4 I Made Wahyu Chandra Satriana, 2013, Kebijakan Formulasi Keadilan Restoratif Dalam Sistem Peradilan Pidana (penelitian), Program Studi Magister (S2) Ilmu Hukum Universitas Udayana, Denpasar.

5 M. Iqbal Hasan, 2002, Pokok-Pokok Materi Metode Penelitian dan Aplikasinya, Cet. I, Ghlmia Indonesia, Jakarta, hlm.43
}

pembuktian dengan alat bukti tertulis yang bersifat otentik mengenai keadaan, peristiwa atau perbuatan hukum dengan demikian Notaris diberikan kewenangan dalam menjalankan jabatannya untuk melayani kebutuhan masyarakat tersebut.

Kewenangan Notaris harus jelas dan tegas dalam peraturan perundang-undangan yang mengatur jabatan notaris, sehingga jika seorang Notaris melakukan suatu tindakan diluar wewenang disebut sebagai perbuatan melanggar hukum. Kewenangan tersebut dikuatkan kembali dalam Pasal 15 ayat 1 UUJN yang menyebutkan mengenai kewenangan Notaris sebagai Pejabat Umum yaitu membuat akta otentik.

Hal tersebut dapat dilihat dari Pasal 1868 Kitab Undang-Undang Hukum Perdata, selanjutnya disebut KUHPerdata, mengenai akta otentik yang berbunyi :

"Suatu akta otentik ialah suatu akta yang dibuat dalam bentuk ditentukan oleh undang-undang, dibuat oleh atau dihadapan pejabat umum yang berwenang untuk itu di tempat akta itu dibuatnya."

Ditegaskan bahwa suatu akta otentik yang dalam bentuknya yang telah ditentukan oleh undangundang tersebut harus dibuat oleh pejabat umum yang berwenang. Dalam bentuk perkataan diatas adanya penunjukan terhadap seorang pejabat umum tetapi tidak menyebutkan secara spesifik mengenai pejabat umum itu sendiri, maka dibuatlah PJN yang dapat disebut sebagai peraturan pelaksana dari Pasal 1868 KUHPerdata, di mana menjelaskan bahwa Notaris-lah yang dimaksud sebagai pejabat umum ${ }^{6}$.

Di dalam Pasal 16 huruf a UUJN, Notaris diwajibkan bertindak jujur, seksama, mandiri, tidak berpihak dan menjaga kepentingan para pihak yang terkait dalam perbuatan hukum. Apabila ketentuan pada UUJN dilanggar terutama dengan memasukkan keterangan palsu ke dalam akta otentik, maka pada fase tersebut Notaris dapat dijadikan sebagai tersangka. Fase berikutnya apabila akta yang dibuat Notaris tersebut terbukti karena kesalahannya atau kesengajaannya oleh karena kehendak jahat, maka pada fase tersebut Notaris yang bersangkutan dapat dijadikan sebagai terdakwa. Apabila pengadilan melalui Majelis Hakim dapat membuktikan secara fakta hukum, Notaris tersebut terbukti bersalah secara sah dan menyakinkan maka pada fase itu Notaris tersebut telah menjadi seorang terpidana melalui suatu keputusan pengadilan yang telah memperoleh kekuatan hukum tetap.

${ }^{6}$ G.H.S.Lumban Tobing, Peraturan Jabatan Notaris,Cet.3, (Jakarta: Erlangga, 1983), hlm. 6 
Dasar pokok sistem hukum pidana di Indonesia yaitu menganut asas legalitas (principle of legality) sebagaimana diatur dalam Pasal 1 ayat (1) KUHP, merupakan asas yang menentukan bahwa tidak ada perbuatan yang dilarang dan diancam dengan pidana jika tidak ditentukan terlebih dahulu dalam perundang-undangan (nullum delictum nulla poena sine praevia lege). Maka tidak ada perbuatan yang dilarang dan diancam dengan pidana jika hal itu terlebih dahulu belum dinyatakan dalam suatu aturan undang-undang ${ }^{7}$.

Standar prosedur, kewenangan, kewajiban dan larangan Notaris sudah diatur dalam UUJN. UndangUndang tersebut disahkan di Jakarta pada tanggal 6 Oktober 2004, sebagaimana ditempatkan dalam Lembaran Negara Republik Indonesia Tahun 2004 Nomor 117 yang terdiri dari 13 Bab dan 92 Pasal semakin mempertegas posisi penting Notaris sebagai pejabat umum yang memberikan kepastian hukum melalui akta otentik yang dibuatnya.

Landasan filosofis lahirnya UUJN adalah terwujudnya jaminan kepastian hukum, ketertiban dan perlindungan hukum yang berintikan kebenaran, dan keadilan. Melalui akta yang dibuatnya, Notaris harus dapat memberikan kepastian hukum kepada masyarakat pengguna jasa Notaris ${ }^{8}$. Akta otentik pada hakikatnya memuat kebenaran formal sesuai dengan apa yang diberitahukan para pihak kepada Notaris. Oleh karena itu, bukan saja Notaris yang harus dilindungi tetapi juga para konsumennya, yaitu masyarakat pengguna jasa Notaris.

Namun Notaris mempunyai kewajiban untuk memasukkan bahwa apa yang termuat dalam akta Notaris sungguh-sungguh telah dimengerti dan sesuai dengan kehendak para pihak yaitu dengan cara membacakannya sehingga menjadi jelas isi akta Notaris serta memberikan akses terhadap informasi termasuk akses terhadap peraturan perundangundangan yang terkait bagi para pihak penandatangan akta Notaris dalam menjalankan jabatannya berperan secara tidak memihak dan bebas (unpartiality and Independency).

UUJN mengatur bahwa ketika Notaris dalam menjalankan tugas jabatannya terbukti melakukan pelanggaran, maka Notaris dapat dikenai atau dijatuhi sanksi, berupa sanksi perdata, administrasi, dan kode etik jabatan Notaris, dan sanksi-sanksi tersebut telah diatur sedemikian rupa dalam UUJN

\footnotetext{
${ }^{7}$ Moeljatno, Op.Cit, hlm. 23

${ }^{8}$ Salim HS. dan Abdullah, Perancangan Kontrak dan MOU, (Jakarta: Sinar Grafika, 2007), hlm. 101

${ }^{9}$ Herlin Budiono, Kumpulan Tulisan Hukum Perdata di Bidang Kenotariatan, (Bandung: Citra Aditya Bakti, 2007), hlm. 22
}

dan Kode Etik Jabatan Notaris. Mengenai pengaturan sanksi pidana diatur dalam peraturan sebelumnya yaitu PJN, tetapi saat ini dalam UUJN tidak mengatur adanya sanksi pidana terhadap Notaris.

Apabila dalam melaksanakan tugasnya seorang Notaris terbukti melakukan kesalahan atau melanggar ketentuan dalam UUJN, maka Notaris tersebut hanya mendapatkan sanksi berupa sanksi administratif atau sanksi perdata. Dalih lain yang bisa dilakukan oleh seorang Notaris adalah bahwa setiap aktifitas yang dilaksanakan diawasi oleh Majelis Pengawas Notaris (selanjutnya disebut MPN).

UUJN yang diharapkan menjadi sandaran bagi seorang Notaris karena semua aturan yang mengenai jabatan Notaris terdapat di UndangUndang tersebut ternyata menjadikan UndangUndang tersebut sebagai celah untuk pembelaan bagi Notaris apabila terkena masalah hukum agar terbebas dari sanksi pidana.

Adapun tindakan Notaris yang merupakan TPN antara lain yaitu ${ }^{10}$ :

1. Membuat surat palsu/yang dipalsukan dan menggunakan surat palsu/yang dipalsukan (pasal 263 ayat (1) dan (2) KUHP);

2. Melakukan pemalsuan terhadap akta otentik (pasal 264 KUHP);

3. Menyuruh mencantumkan keterangan palsu dalam akta otentik (pasal $266 \mathrm{KUHP}$ );

4. Melakukan, menyuruh, turut serta melakukan (pasl 55 jo pasal 263 ayat (1) dan (2) KUHP atau pasal 264 atau pasal 266;

5. Membantu membuat surat palsu/atau yang dipalsukan dan menggunakan surat palsu/yang dipalsukan (pasal 56 ayat (1) dan (2) jo pasal 263 ayat (1) dan (2) KUHP atau pasal 264 atau pasal 266.

Rumusan pasal 263, 264, 266 KUHP di dalamnya terdapat istilah "dengan maksud", artinya apabila Notaris menginginkan terjadinya suatu akibat yaitu merugikan para pihak atau salah satu pihak atau memiliki tujuan tertentu terhadap pembuatan akta palsu (pemalsuan akta) tersebut, maka dapat disimpulkan bahwa Notaris mengetahui secara jelas perbuatannya dan menginginkan (menghendaki) tejadinya suatu akibat. Notaris memiliki kemampuan bertanggung jawab terhadap perbuatannya tersebut.

\section{Sanksi terhadap notaris yang melakukan tindak pidana menurut perundang-undangan di Indonesia}

Pengaturan Jabatan Notaris di Indonesia di atur dalam Peraturan Jabatan Notaris (PJN) Reglement Op Het Notaris ambt in Indonesie (Stb. 1860:3)

\footnotetext{
${ }^{10}$ Habib Adjie, Buku I, Op.Cit. hlm.76
} 
sebagaimana telah diubah terakhir dalam lembaran Negara tahun 1954 Nomor 101; Ordonantie 16 Sepetember 1931 tentang Honorarium Notaris; Undang-undang Nomor 33 Tahun 1954 tentang Wakil Notaris dan Wakil Notaris Sementara Lembaran Negara Tahun 1954 Nomor 101, Tambahan Lembaran Negara Nomor 700); Undang-Undang Nomor 8 Tahun 2004 tentang Perubahan Atas Undang-Undang Nomor 2 Tahun 1986 tentang Peradilan Umum (Lembaran Negara Republik Indonesia Tahun 2004 Nomor 34, Tambahan Lembaran Negara Republik Indonesia Nomor 4379); dan Peraturan Pemerintah Nomor 11 Tahun 1949 Tentang Sumpah/Janji Jabatan Notaris ${ }^{11}$.

Pasal-pasal yang terdapat dalam PJN adalah menyalin dari pasal-pasal Notarisewet yang berlaku di Belanda. Jika diperhatikan isi pasal dalam PJN tersebut terdiri dari 66 pasal, dari 39 pasal mengandung ketentuan hukuman, disamping banyak sanksi-sanksi untuk membayar penggantian biaya ganti rugi dan bunga. Ke-39 pasal tersebut terdiri dari 3 pasal mengenai hal-hal yang menyebabkan hilangnya jabatan, 5 pasal tentang pemecatan, 9 pasal tentang pemecatan sementara dan 22 pasal mengenai pidana denda serta 7 pasal tentang penggantian biaya, ganti rugi dan bunga ${ }^{12}$.

Pada hakekatnya seluruh pasal dalam PJN mengandung ancaman hukuman, dengan adanya ketentuan dalam pasal 50 PJN yang menyatakan bahwa Pengadilan Negeri dapat mengambil tindakan, apabila Notaris mengabaikan keluhuran martabat atau jabatannya, melakukan kesalahan-kesalahan lain, baik didalam maupun diluar menjalankan jabatannya sebagai Notaris ${ }^{13}$.

Dengan demikian, dalam upaya penanggulangan dan pencegahan kejahatan tidak cukup hanya dengan pendekatan secara integral, tetapi pendekatan sarana penal dan non penal harus didukung juga dengan meningkatnya kesadaran hukum masyarakat. Kesadaran hukum masyarakat merupakan salah satu bagian dari budaya hukum. Padahal budaya hukum juga mencakup kesadaran hukum dari pihak pelaku usaha, parlemen, pemerintah dan aparat penegak hukum salah satunya yaitu Notaris. Mengingat keberadaan UUJN yang tidak memiliki sanksi pidana, maka pelaksanaa UUJN hanya mendasarkan pada kesadaran etika moral belaka.

\footnotetext{
${ }^{11}$ Hermawan, "Implementasi Undang-Undang Nomor 30 Tahun 2004 tentang Jabatan Notaris", http://herman-notary.blogspot.com/2012/06/implementasiundang-undang-no-30-tahun.html, diunduh 6 Februari 2018.

${ }^{12}$ G.H.S. Lumban Tobing, Op.Cit, hlm.312

13 Ibid, hlm. 313
}

Penggunaan upaya penal (sanksi pidana) dalam mengatur masyarakat (lewat perundang-undangan) pada hakikatnya merupakan bagian dari suatu langkah kebijakan (policy). Mengingat berbagai keterbatasan dan kelemahan hukum pidana, maka penggunaan upaya penal seyogianya dilakukan dengan lebih hati-hati, cermat, hemat, selektif dan limitatif.

Dengan adanya lebih dari satu jenis sanksi yang dapat dijatuhkan terhadap Notaris, berkaitan dengan kumulasi sanksi terhadap Notaris. Dalam kaidah peraturan perundang-undangan di bidang hukum administrasi, sering tidak hanya memuat satu macam sanksi, tetapi terdapat beberapa sanksi yang diberlakukan secara kumulasi, adakalanya suatu ketentuan peraturan perundang- undangan tidah hanya mengancam pelanggarnya dengan sanksi pidana, tapi pada saat yang sama mengancamnya dengan sanksi administrasi ${ }^{14}$.

Pemberian sanksi pidana terhadap Notaris dapat dilakukan dengan batasan, yaitu jika :

1. Ada tindakan hukum dari Notaris terhadap aspek formal (kepastian hari, tanggal, bulan, tahun dan pukul menghadap) akta yang sengaja, penuh kesadaran dan keinsyafan serta direncanakan, bahwa akta yang dibuat di hadapan Notaris atau oleh Notaris bersama-sama (sepakat) untuk dijadikan dasar untuk melakukan suatu tindak pidana.

2. Ada tindakan hukum dari Notaris dalam membuat akta di hadapan atau oleh Notaris yang jika diukur berdasarkan UUJN tidak sesuai dengan UUJN.

3. Tindakan Notaris tersebut tidak sesuai menurut instansi yang berwenang untuk menilai tindakan suatu Notaris, dalam hal ini MPN.

Upaya pencegahan terhadap kejahatan di lingkungan profesional, salah satunya profesi Notaris, dapat dilakukan melalui upaya penal, yaitu dengan cara Klausula penundukan pada undang-undang. Bahwa setiap undang-undang mencantumkan dengan tegas sanksi pidana yang dapat diancamkan kepada pelanggarnya. Dengan demikian menjadi pertimbangan bagi para profesional, tidak ada jalan lain kecuali taat. Jika terjadi tindak pidana berarti yang bersangkutan bersedia dikenai sanksi yang cukup memberatkan atau merepotkan baginya. Ketegasan sanksi pidana ini lalu dicantumkan dalam rumusan undang-undang profesi yang memberlakukan sanksi kepada setiap anggotanya ${ }^{15}$.

\footnotetext{
${ }^{14}$ Habib Adjie, Buku I, Op.Cit, hlm. 119

15 Muhammad Abdul Kadir, Etika Profesi Hukum, (Bandung: Citra Aditya Bakti, 1997), hlm. 86
} 
Dalam menegakkan sanksi administratif terhadap Notaris yang menjadi instrumen pengawasan yaitu MPN yang mengambil langkah-langkah preventif, untuk melaksanakan kepatuhan dan untuk memaksakan kepatuhan agar sanksi-sanksi tersebut dapat dilaksanakan ${ }^{16}$.

Langkah-langkah preventif dilakukan dengan melakukan pemeriksaan secara berkala 1 (satu) kali dalam satu tahun setiap waktu yang dianggap perlu untuk memeriksa ketaatan Notaris dalam menjalankan tugas jabatannya yang dilihat dari pemeriksaan protokolnya oleh MPD. Kemudian MPD menyelenggarakan sidang untuk memeriksa adanya dugaan pelanggaran Kode Etik Notaris atau pelanggaran pelaksanaan jabatan Notaris. MPD menerima laporan dari masyarakat mengenai adanya dugaan pelanggaran Kode Etik Notaris atau pelanggaran ketentuan dalam UUJN. Jika hasil pemeriksaan MPD menemukan pelanggaran, maka MPD tidak dapat menjatuhkan sanksi yang represif kepada Notaris melainkan hanya dapat melaporkan kepada MPW.

MPW dapat melakukan langkah preventif dengan menyelenggarakan sidang untuk memeriksa dan mengambil keputusan atas laporan masyarakat yang disampaikan melalui MPW dan memanggil Notaris sebagai terlapor untuk dilakukan pemeriksaan, MPW juga memeriksa dan memutus hasil pemeriksaan MPD. MPW dapat melakukan langkah represif, yaitu menjatuhkan sanksi berupa teguran lisan atau tertulis dan sanksi ini bersifat final, dan mengusulkan pemberian sanksi terhadap Notaris kepada MPP berupa pemberhentian sementara 3 (tiga) bulan sampai dengan 6 (enam) bulan, atau pemberhent ian dengan tidak hormat. MPP tidak melakukan tindakan preventif, tapi menyelenggarakan sidang untuk memeriksa dan mengambil keputusan dalam tingkat banding terhadap penjatuhan sanksi dan penolakan cuti, tapi tindakan represif berupa penjatuhan sanksi pemberhentian sementara, dan mengusulkan pemberian sanksi berupa pemberhentian dengan tidak hormat kepada Menteri.

Sebelum menjatuhkan sanksi administratif berupa pemberhentian dengan tidak hormat terhadap Notaris tersebut, ditempuh dulu penjatuhan sanksi berupa teguran lisan atau tertulis, untuk kemudian mengusulkan pemberian sanksi pemberhentian sementara 3 (tiga) bulan sampai dengan 6 (enam) bulan dan selanjutnya mengusulkan untuk pemberhentian dengan tidak hormat dari jabatannya. Hal tersebut dapat dilakukan untuk memberikan

\footnotetext{
${ }^{16}$ Ibid., hlm.92
}

kesempatan kepada yang bersangkutan untuk membela diri dan memperbaiki diri.

Dalam Pasal 85 UUJN juga ditentukan ada 5 (lima) jenis sanksi administratif, yaitu : teguran lisan, teguran tertulis, pemberhentian sementara, pemberhentian dengan hormat dan pemberhentian tidak hormat. Dengan adanya sanksi administratif ini Notaris tersebut tidak akan melakukan perbuatan yang dapat merugikan dan merusak dirinya sendiri serta jabatannya. Jika dilihat dari sudut politik kriminal, maka upaya non penal menduduki posisi kunci dan strategis dari keseluruhan upaya politik kriminal. Akan tetapi kegagalan dalam menggarap posisi strategis ini justru akan berakibat fatal bagi usaha penanggulangan kejahatan. Oleh karena itu suatu kebijakan kriminal harus dapat mengintegrasikan dan mengharmonisasikan seluruh kegiatan yang non penal kedalam suatu sistem kegiatan Negara yang teratur dan terpadu.

Disamping itu upaya-upaya non penal juga dapat ditempuh dengan cara menyehatkan sistem peradilan Indonesia lewat kebijakan sosial dan dengan menggali berbagai potensi yang ada didalam masyarakat itu sendiri, juga dapat pula upaya nonpenal itu digali dari berbagai sumber lainnya yang juga mempunyai potensi efek-preventif dari aparat penegak hukum.

\section{PENUTUP}

1. Perbuatan yang merupakan tindak pidana yang bisa dilakukan oleh notaris menurut hukum positif saat ini

Klasifikasikan unsur-unsur TPN tersebut yaitu :

a. Pemalsuan, terhadap akta (akta fiktif), keterangan dalam akta, legalisasi, waarmerking, pencocokan fotocopy, dan tanda tangan.

b. Penggelapan, bahwa mengaku sebagai milik sendiri segala sesuatu barang sebagian/ seluruhnya yang ada dalam kekuasaan Notaris, dititipkan dengan dasar kepercayaan kerena kewenangan Notaris yang bukan milik/kepunyaan Notaris.

c. Penipuan, bahwa melakukan kebohongan/ rangkaian kebohongan/tipu muslihat untuk menguntungkan Notaris secara melawan hukum/tidak sesuai dengan ketentuan.

Hukum positif saat ini telah berupaya mencegah terjadinya tindak pidana yang dilakukan oleh Notaris, namun adanya sanksi yang berat tidak menjadi jaminan Notaris tidak melakukan Tindak Pidana.

2. Sanksi terhadap notaris yang melakukan tindak pidana menurut perundang-undangan di Indonesia 
Tidak adanya sanksi pidana dalam UUJN, peraturan yang mengatur mengenai sanksi terhadap Notaris menjadi kurang sempurna, karena tidak adanya sanksi yang tegas dan sanksi yang jelas akan tindakan-tindakan yang dikategorikan tindak pidana khusus yang hanya dapat dilakukan oleh Notaris yaitu Tindak Pidana Notaris (TPN), yang kenyataannya belum ada satupun peraturan yang mengatur mengenai hal tersebut. Sanksi yang tersisa dalam UUJN hanyalah murni sanksi administratif dan sanksi perdata saja.

\section{DAFTAR PUSTAKA}

Abdul Ghofur Anshori, 2009, Lembaga Kenotariatan Indonesia Perspektif Hukum dan Etika, UII Press, Yogyakarta,

G.H.S.Lumban Tobing, Peraturan Jabatan Notaris,Cet.3, (Jakarta: Erlangga, 1983)

Habib Adjie, 2014, Hukum Notaris Indonesia, Refika Aditama, Bandung
Herlin Budiono, Kumpulan Tulisan Hukum Perdata di Bidang Kenotariatan, (Bandung: Citra Aditya Bakti, 2007)

I Made Wahyu Chandra Satriana, 2013, Kebijakan Formulasi Keadilan Restoratif Dalam Sistem Peradilan Pidana (penelitian), Program Studi Magister (S2) Ilmu Hukum Universitas Udayana, Denpasar.

M. Iqbal Hasan, 2002, Pokok-Pokok Materi Metode Penelitian dan Aplikasinya, Cet. I, Ghlmia Indonesia, Jakarta

Muhammad Abdul Kadir, Etika Profesi Hukum, (Bandung: Citra Aditya Bakti, 1997)

Salim HS. dan Abdullah, Perancangan Kontrak dan MOU, (Jakarta: Sinar Grafika, 2007),

Wawan Setiawan, "Sikap Profesionalisme Notaris Dalam Pembuatan Akta Otentik", Media Notariat, (Edisi Mei-Juni 2004) 